\title{
Assessment of residential exposure to Volatile Organic Compounds (VOCs) and Carbon Dioxide $\left(\mathrm{CO}_{2}\right)$
}

\author{
Mentese S. ${ }^{*}$ and Tasdibi D. \\ Canakkale Onsekiz Mart University, Faculty of Engineering, Department of Environmental Engineering, Terzioglu campus, Canakkale, \\ 17100, Turkey
}

Received: 24/02/2017, Accepted: 21/12/2017, Available online: 19/01/2018

*to whom all correspondence should be addressed: e-mail: sibelmentese@gmail.com; sibelm@comu.edu.tr

\begin{abstract}
There is increasing concern about indoor air pollution worldwide due to its adverse health effects. One of the predominant indoor air pollutant groups is assumed to be volatile organic compounds (VOCs), including a variety of hydrocarbons with different functional groups. Among VOCs, some species have carcinogenic effects, and some are widely used in many consumer products. $\mathrm{CO}_{2}$ is assumed to be an indicator of ventilation adequacy. Thus, elevated indoor $\mathrm{CO}_{2}$ levels are linked with the discomfort level of occupants. Residential exposure to VOCs and $\mathrm{CO}_{2}$ in 6 different homes located in 3 different towns in Canakkale, Turkey were assessed for about a year. Also, a home inventory was used to identify the potential sources of VOCs and $\mathrm{CO}_{2}$ as well as environmental concerns of the occupants. The highest levels of indoor $\mathrm{CO}_{2}$, total volatile organic compounds (TVOC), benzene, toluene, and xylenes were found at industrial sampling sites. A connection between aspects of the outdoor environment (i.e. availability of potential sources) and residential exposure to air pollutants was found. Also, some activities (e.g. heating fuel type, house cleaning frequency, etc.) and factors (e.g. characteristics of the outdoor environment) influenced residential exposure to VOCs and $\mathrm{CO}_{2}$.
\end{abstract}

Keywords: Indoor Air Pollution, Volatile Organic Compounds, Carbon dioxide, Residential exposure to air pollutants.

\section{Introduction}

Residential exposure to air pollutants is crucial due to the potential health effects of the pollutants. This is important considering more time is spent indoors than outdoors, particularly in urban environments (i.e. in workplaces, homes, and while commuting). Also, there are numerous sources of air pollutants in indoor environments, in addition to outdoor air pollutants penetrating indoors by ventilation and/or infiltration. Among the indoor air pollutants, VOCs are one of the most known and monitored compound groups due to their high availability in indoor environments (e.g. building/decoration products, household agents, consumer products etc.) and their potential health hazards (Wieslander et al., 1996; Baek et al., 1997; Rehwagen et al., 2003; Mentese et al., 2012; US EPA, 2012). VOC exposure is linked with adverse health effects such as discomfort, irritation and diseases (Arif et al., 2007; Mitchell et al., 2007; Billionnet et al., 2011). Most studies have focused on levels of indoor VOCs without considering several factors or availability of their potential sources. In fact, residential VOC levels are influenced by multiple sources and/or multiple factors both originating from indoor and outdoor environments, rather than a single source or a single factor.

Levels of indoor Carbon dioxide $\left(\mathrm{CO}_{2}\right)$ are assumed to be an indicator of the adequacy of ventilation and/or occupancy and thus elevated indoor $\mathrm{CO}_{2}$ levels are directly linked with the discomfort level of the occupants, resulting in dissatisfaction (Lee and Chang, 2000; Olesen, 2004; Heudorf et al., 2009; Mentese et al., 2009; ANSI/ASHRAE, 2016a; b). Also, some studies showed associations between elevated indoor $\mathrm{CO}_{2}$ exposure and human decision-making performance and school absenteeism (Shendell et al., 2004a; b; Satish et al., 2012). A European standard, EN 13779, considers the human comfort level for $\mathrm{CO}_{2}$ by comparing indoor $\mathrm{CO}_{2}$ levels with outdoor $\mathrm{CO}_{2}$ levels at the time of measurement (EN, 2007).

Most of the studies available in the literature focus mostly on residential VOCs levels without considering the presence of potential sources or occupant-related activities as well as the potential contribution of the outdoor environment. The aims of this study are to assess long term indoor $\mathrm{VOC}$ and $\mathrm{CO}_{2}$ exposure in six different homes located in three different towns in Canakkale, Turkey and to find the correlations among indoor VOCs and $\mathrm{CO}_{2}$ exposure and several factors related to indoor air pollution, by using the data gathered from the home inventories.

\section{Materials and Methods}

\subsection{Study design}

Residential levels of VOCs and $\mathrm{CO}_{2}$ were measured in homes $(n=6)$ in three different towns in Canakkale, Turkey: i) Center: urban site, ii) Can: semi-urban site with industrial activities, and iii) Lapseki: rural site. Locations of the sampling sites are shown in Figure 1. 
Three of the homes are located in the central town (U1U3), one home is located in Lapseki (R1), and two homes are located in Can (11-12). All indoor environments were selected randomly among the volunteer participants.
Indoor VOC samples were collected every month at the sampling sites for about a year. Also, air temperature (으), relative humidity $(\mathrm{RH}, \%)$, and $\mathrm{CO}_{2}(\mathrm{ppm})$ levels were measured at the time of sampling.

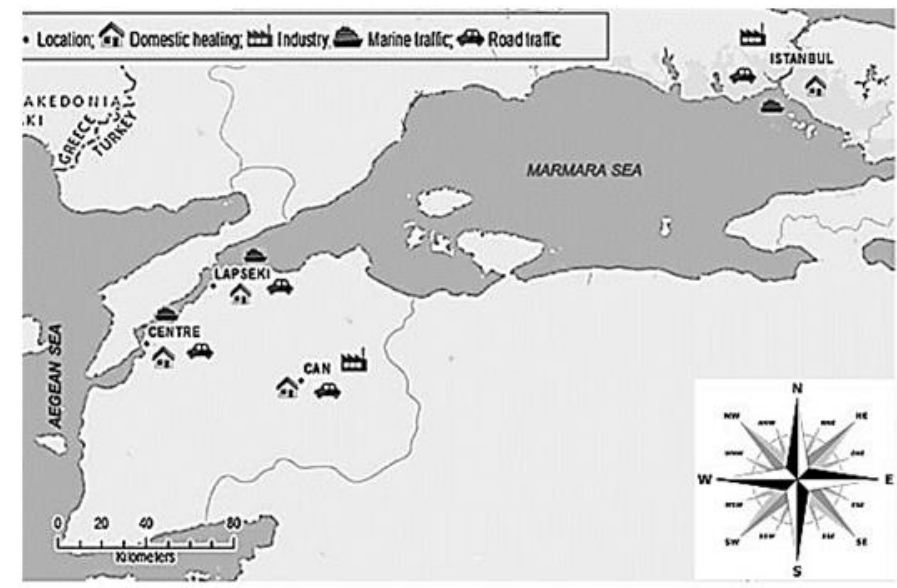

Figure 1. Locations of the sampling sites

\subsection{Sampling and analyses}

Monthly indoor VOCs samples were collected from the sampling sites by passive sampling principle throughout one year (ISO, 2003). VOC samples were collected on Tenax TA-Carbograph 1TD dual-bed sorbent tubes. Indoor VOC samples were collected from living rooms of the sampling sites. VOC samples were analyzed by Thermal Desorber Gas Chromatography - Flame Ionization Detector. Details about the analysis method can be found in Mentese et al., 2015; 2016b). Concentration of total volatile organic compounds (TVOC) were quantified as toluene-equivalent by summing up all signals from $\mathrm{C}_{6}$ ( $n$-hexane) to $\mathrm{C}_{16}$ ( $n$ hexadecane) (ECA, 1997; ISO, 2004). The limit of quantification for each compound was calculated (US EPA, 1999; Mentese et al., 2015) to be around $1.0 \mu \mathrm{g} \mathrm{m}^{-3}$ as an average. Quality assurance and quality control procedures followed in this study were the same as stated in Mentese et al.; (2015).

Both indoor and outdoor air $\mathrm{CO}_{2}$ concentrations were measured simultaneously with a real-time monitoring device together with air temperature and $\mathrm{RH}$ measurements.

Table 1. Information regarding the environments of the sampling points

\begin{tabular}{|c|c|c|c|c|c|c|}
\hline $\begin{array}{c}\text { Building/ } \\
\text { Environmental Factors }\end{array}$ & U-1 & U-2 & U-3 & R-1 & $\mathrm{I}-1$ & $1-2$ \\
\hline Building type & $\begin{array}{l}\text { multi-storey } \\
\text { apartment }\end{array}$ & $\begin{array}{l}\text { multi-storey } \\
\text { apartment }\end{array}$ & $\begin{array}{l}\text { multi-storey } \\
\text { apartment }\end{array}$ & $\begin{array}{l}\text { multi-storey } \\
\text { apartment }\end{array}$ & $\begin{array}{l}\text { detached } \\
\text { house }\end{array}$ & $\begin{array}{c}\text { detached } \\
\text { house }\end{array}$ \\
\hline Floor number & 3 & 5 & 4 & 2 & 1 & 1 \\
\hline Distance to traffic & moderate & far & moderate & moderate & far & far \\
\hline Room area $\left(m^{2}\right)$ & 10 & 26 & 24 & 18 & 10 & 15 \\
\hline Flooring material type & laminate & laminate & wood & glazed tile & concrete & laminate \\
\hline Last floor covering time (year) & 12 & 6 & 15 & 10 & 28 & 1 \\
\hline $\begin{array}{l}\text { Wooden product amount in } \\
\text { the room }\end{array}$ & moderate & moderate & much & moderate & less & moderate \\
\hline Last wall painting time (year) & 3 & 5 & 1 & 1 & $<1$ & 1 \\
\hline $\begin{array}{l}\text { Weekly house cleaning } \\
\text { frequency }\end{array}$ & $\geq 2$ times & once & once & once & $\geq 2$ times & $\geq 2$ times \\
\hline Pesticide usage & yes & yes & no & yes & yes & yes \\
\hline $\begin{array}{l}\text { Naphthalene/air freshener } \\
\text { usage }\end{array}$ & no & yes & yes & yes & yes & no \\
\hline Cooking fuel type & natural gas & natural gas & natural gas & $\begin{array}{l}\text { butane/ } \\
\text { propane } \\
\text { cylinder }\end{array}$ & $\begin{array}{l}\text { butane/ } \\
\text { propane } \\
\text { cylinder }\end{array}$ & $\begin{array}{c}\text { coal \& } \\
\text { butane/ } \\
\text { propane } \\
\text { cylinder }\end{array}$ \\
\hline Heating fuel type & coal & natural gas & natural gas & coal & coal \& wood & coal \\
\hline $\begin{array}{l}\text { Average daily ventilation } \\
\text { duration (hour) }\end{array}$ & 3.8 & 12.3 & 7 & 7 & 2.9 & 7.8 \\
\hline Building age (year) & 10 & 6 & 15 & 17 & 28 & 17 \\
\hline
\end{tabular}




\subsection{Home inventory}

A home inventory was given to an occupant of each sampling site, including building and environmental parameters as well as information regarding the occupants of the sampling sites to research the potential sources of residential VOC exposure and occupants' indoor air quality perception (Mentese and Tasdibi, 2016a; b). The key points of the home inventory were categorized into 3 groups: i) building factors, ii) environmental factors, and iii) occupant- related factors.

\section{Results and Discussion}

3.1. Information regarding the sampling points and the occupants

Several building and environmental factors were taken into account to find the potential sources of residential VOC and $\mathrm{CO}_{2}$ exposure. These data were gathered from the home inventories on a seasonal basis. None of the sampling points were equipped with a mechanical ventilator. Furthermore, none of the occupants were smoking at home. Information regarding the building/environmental factors of the sampling points is given in Table 1.

Information regarding the occupants of each home (general health condition, time spent at home, bad odor complaint) is shown in Table 2.

Table 2. Information regarding the occupants of the sampling points

\begin{tabular}{|c|c|c|c|c|c|c|c|}
\hline Parameter & Season & U-1 & $\mathrm{U}-2$ & U-3 & R-1 & I-1 & $1-2$ \\
\hline & $\mathrm{F}$ & Good & Moderate & Very good & Very good & Good & Good \\
\hline General Health & W & Good & Moderate & Good & Very good & Good & Good \\
\hline \multirow[t]{2}{*}{ Condition* } & Sp. & Good & Good & Good & Good & Good & Good \\
\hline & $\mathrm{S}$ & Good & Moderate & Good & Good & Good & Moderate \\
\hline \multirow{4}{*}{ Time spent indoors (h) } & $\mathrm{F}$ & 16 & 15 & 15 & 24 & 20 & 13 \\
\hline & W & 16 & 18 & 20 & 24 & 24 & 12 \\
\hline & Sp. & 16 & 18 & 17 & 22 & 20 & 12 \\
\hline & $\mathrm{S}$ & 16 & 18 & 20 & 22 & 24 & 8 \\
\hline \multirow{4}{*}{ Bad odor at home } & $\mathrm{F}$ & No & No & No & Yes & No & Yes \\
\hline & W & No & No & No & Yes & Yes & No \\
\hline & Sp. & Yes & No & No & Yes & Yes & No \\
\hline & $\mathrm{S}$ & No & No & No & Yes & Yes & No \\
\hline
\end{tabular}

*General health condition was scored from very good to very bad; F: fall, W: winter, Sp.: spring, S: summer

Table 3. Annual average values for indoor air temperature $\left({ }^{\circ} \mathrm{C}\right)$ and $\mathrm{RH}(\%)$ at three sampling sites*

\begin{tabular}{cccc}
\hline Variable & Centre (U1-U3) & Lapseki (R1) & Can (I1-I2) \\
\hline Temperature & $22.8 \pm 1.1(20.8-25.5)$ & $23.6 \pm 1.1(20.4-25.6)$ & $23.7 \pm 1.1(21.3-26.7)$ \\
\hline RH & $51.6 \pm 3.5(45.4-61.3)$ & $51.2 \pm 3.7(45.5-59.3)$ & $50.4 \pm 4.3(43.3-58.6)$ \\
\hline
\end{tabular}

${ }^{*}$ mean \pm standard deviation (minimum-maximum)

\subsection{Climatic parameters}

Annual average outdoor air temperature and $\mathrm{RH}$ in Canakkale city were recorded as $16.2{ }^{\circ} \mathrm{C}$ and $73.1 \%$, respectively. Annual average indoor air temperature and $\mathrm{RH}$ at the sampling points were around $22-24{ }^{\circ} \mathrm{C}$ and $50-52 \%$, respectively, and no big differences were observed in the study towns in terms of both indoor air temperature and RH levels (see Table 3).

\subsection{Indoor VOC Levels}

Annual average concentrations of VOCs are given in Table 4. Accordingly, the highest TVOC, benzene, toluene, and xylenes levels were observed at I-1 and I-2 sampling points, in descending order, while the lowest concentration values, in general, were observed at U-2. Monthly variation of indoor TVOC, benzene, toluene, and xylenes at the sampling points are given in Figure 2. As can be seen from the figure, no clear seasonal variations in VOC levels were observed at the sampling sites, indicating constant sources in the indoor environment throughout the year for those VOCs. Indoor benzene levels were slightly lower in the spring and summer seasons compared to the other seasons. Also, the largest concentration variations occurred in I-1 for both indoor TVOC and indoor toluene levels, compared to other sampling points. Jia et al., (2008a) monitored VOCs in Michigan, USA and they found small or inconsistent seasonal changes in VOCs, similar to the results of this study. Some studies have shown that indoor VOC levels show a seasonal pattern, particularly in non-tropical areas due to the seasonal variation in heating/cooling applications and the intensity of sunlight (Mohamed et al., 2002; Rehwagen et al., 2003; Mentese et al., 2012; Mentese et al., 2015;).

Table 4. Annual average concentrations of VOCs at the sampling points $\left(\mu \mathrm{g} / \mathrm{m}^{3}\right)$

\begin{tabular}{|c|c|c|c|c|}
\hline Sampling point & TVOC & Benzene & Toluene & Xylenes \\
\hline U-1 & $683.4 \pm 513.5$ & $1.0 \pm 0.6$ & $11.4 \pm 4.5$ & $3.5 \pm 0.7$ \\
\hline U-2 & $239.5 \pm 132.1$ & $0.9 \pm 0.6$ & $25.4 \pm 31.6$ & $3.8 \pm 2.8$ \\
\hline U-3 & $347.9 \pm 163.0$ & $1.6 \pm 1.1$ & $19.5 \pm 9.6$ & $4.8 \pm 2.5$ \\
\hline R-1 & $779.6 \pm 596.0$ & $2.4 \pm 1.6$ & $6.0 \pm 2.5$ & $3.2 \pm 1.7$ \\
\hline $\mathrm{I}-1$ & $1334.4 \pm 1471$ & $4.4 \pm 4.5$ & $184.2 \pm 278.2$ & $22.0 \pm 39.0$ \\
\hline $1-2$ & $1053.0 \pm 898$ & $2.4 \pm 1.6$ & $47.0 \pm 60.1$ & $8.2 \pm 3.4$ \\
\hline
\end{tabular}




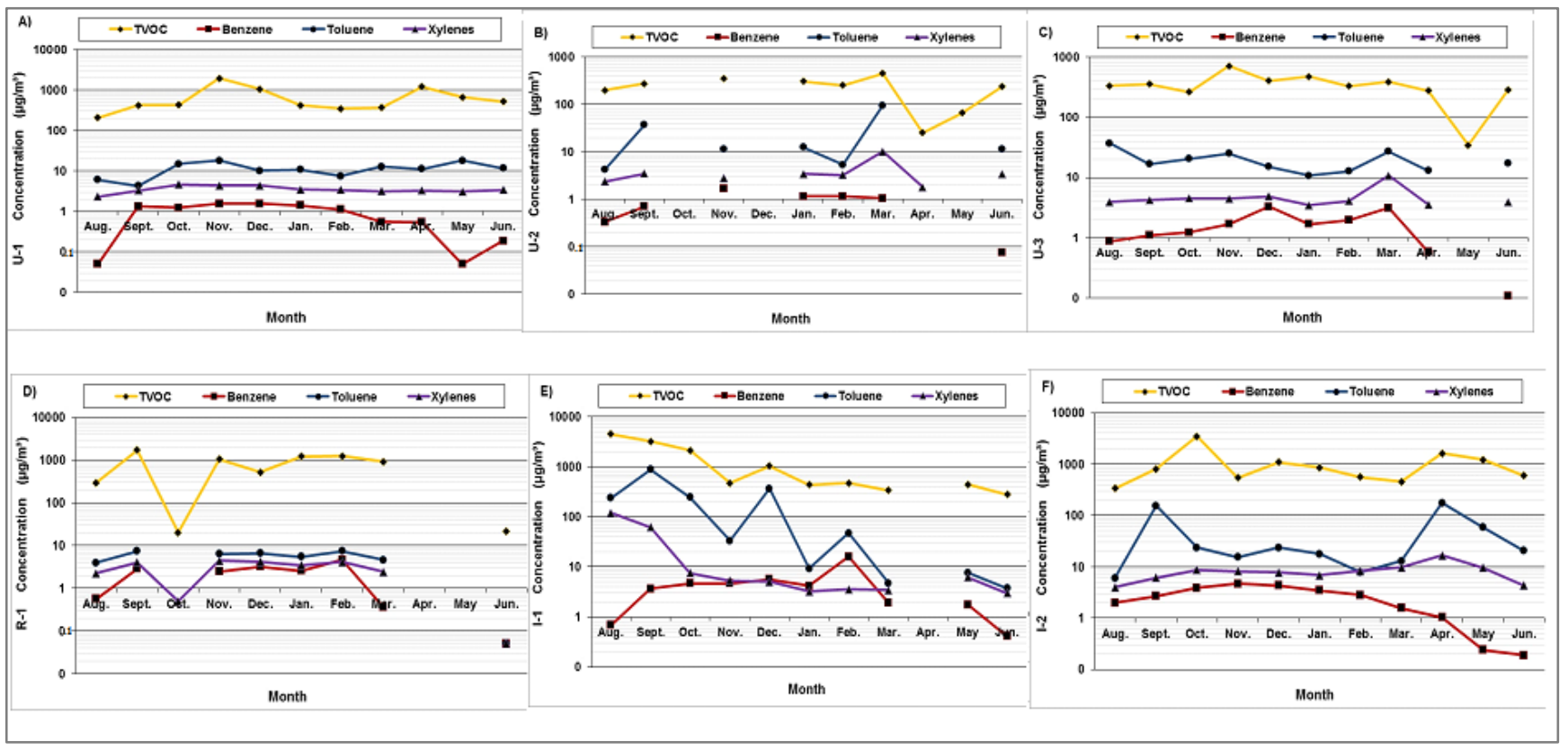

Figure 2. Monthly concentrations of indoor TVOC, benzene, toluene, and xylenes at the sampling points $\left(\mu \mathrm{g} / \mathrm{m}^{3}\right)$, in log scale

Table 5. Annual average concentrations* of $\mathrm{CO}_{2}$ at the sampling points (ppm)

\begin{tabular}{ccccccc}
\hline Sampling point & $\mathbf{U}-1$ & $\mathbf{U}-2$ & $\mathbf{U}-3$ & $\mathbf{R - 1}$ & $\mathbf{I}-1$ & $\mathbf{I - 2}$ \\
\hline In $-\mathrm{CO}_{2}$ & $798 \pm 221$ & $778 \pm 122$ & $667 \pm 177$ & $823 \pm 508$ & $868 \pm 103$ & $978 \pm 278$ \\
\hline Out $-\mathrm{CO}_{2}$ & $468 \pm 23$ & $514 \pm 127$ & $446 \pm 32$ & $449 \pm 35$ & $459 \pm 48$ & $489 \pm 74$ \\
\hline I/O ratio $-\mathrm{CO}_{2}$ & $1.6 \pm 0.4$ & $1.3 \pm 0.6$ & $1.3 \pm 0.2$ & $1.6 \pm 0.5$ & $1.9 \pm 0.2$ & $2.0 \pm 0.7$ \\
\hline
\end{tabular}

*mean \pm standard deviation

\section{4. $\mathrm{CO}_{2}$ Levels}

It was assumed that indoor $\mathrm{CO}_{2}$ level is a surrogate for other occupant-related pollutants and ventilation adequacy (Apte et al., 2000). Annual average $\mathrm{CO}_{2}$ levels measured both indoors and outdoors and calculated indoor to outdoor $(\mathrm{I} / \mathrm{O})$ ratios of $\mathrm{CO}_{2}$ at the sampling sites are given in Table 5. According to the table, indoor $\mathrm{CO}_{2}$ levels were found to be higher than those measured outdoors (I/O ratios $>1.0$ ). The biggest difference between indoor $\mathrm{CO}_{2}$ levels and outdoor $\mathrm{CO}_{2}$ levels as well as the highest indoor $\mathrm{CO}_{2}$ levels were found atl- 2 and $\mathrm{I}-1$, whereas the lowest differences in $\mathrm{CO}_{2}$ levels between indoor and outdoor as well as the lowest indoor $\mathrm{CO}_{2}$ levels were found at U-3 and U-2.

\subsection{Exposure Assessment}

Residential exposure to VOCs and $\mathrm{CO}_{2}$ were assessed for about a year in different homes located in different towns. It was found that there is a connection with aspects of the outdoor environment (i.e. availability of potential sources of air pollutants) and residential exposure to air pollution. Also, some activities (e.g. heating fuel type, house cleaning frequency, etc.) and factors (e.g. characteristics of the outdoor environment: urban, rural or industrial) influence residential exposure to VOCs and $\mathrm{CO}_{2}$. Similarly, Jia et al. (2008a) imply the importance of both indoor and outdoor sources for VOCs exposure.
Home inventories showed that time spent at home by the occupants was linked with bad odor at home. As the time spent indoors increases, bad odor perception starts to occur, particularly it was more frequent for R-1 and I-1 sampling points where the occupants spent most of their time at home. Also, in parallel to bad odor observations at home, VOCs levels at I-1 and R-1 were observed to be higher compared to U-2 and U-3 where no bad odor was observed. General health conditions of the occupants showed variation throughout the study period and no clear links were found between general health conditions, time spent indoors and bad odor observation at home. Moreover, no bad odor complaint was observed at U-3 where the lowest annual indoor $\mathrm{CO}_{2}$ level and the second lowest annual TVOC levels were observed. Furthermore, the highest indoor $\mathrm{CO}_{2}$ levels were encountered in industrial sampling points where the highest TVOC, benzene, toluene, and xylene levels were observed at the same time, while the lowest indoor $\mathrm{CO}_{2}$ levels were found in sampling sites located in the urban town where the lowest values for VOCs were observed.

Annual average values for outdoor $\mathrm{CO}_{2}$ levels were found to be similar among the sampling points of this study. Indoor $\mathrm{CO}_{2}$ levels were more than 200 ppm, higher than the outdoor air $\mathrm{CO}_{2}$ levels at the time of the study and reached as high as $500 \mathrm{ppm}$ in the industrial town. According to EN 13779 (2007), indoor air was classified into 4 groups (IDA 14) according to indoor air $\mathrm{CO}_{2}$ levels subtracted from 
outdoor air $\mathrm{CO}_{2}$ level. Sampling sites of this study fell in IDA1 (indoor $\mathrm{CO}_{2}$ - outdoor $\mathrm{CO}_{2} \leq 400 \mathrm{ppm}$ ) and IDA-2 (indoor $\mathrm{CO}_{2}$ - outdoor $\mathrm{CO}_{2}=400-600 \mathrm{ppm}$ ) classes in terms of $\mathrm{CO}_{2}$ levels due to indoor sources/activities. It has been known that $\mathrm{CO}_{2}$ is a major bio-indicator of occupancy in areas with no proximity to any known $\mathrm{CO}_{2}$ source (Mentese et al., 2009).

Another interesting finding of this study is the strong linkage between exposure to indoor air pollutants and the type of heating fuels. The lowest levels of indoor VOCs as well as the lowest $1 / 0$ ratios for $\mathrm{CO}_{2}$ (i.e. 1.3) were encountered in $\mathrm{U}-2$ and $\mathrm{U}-3$ where the heating fuel was natural gas, whereas the highest indoor VOCs levels were encountered in I-1 where both coal and wood were used as heating fuel. In general, combustion of solid fuels (i.e. wood and coal) produces more emissions than combustion of Liquefied petroleum gas (LPG) (Zhang and Smith, 1996). Another study showed that stove type (gas or electric) is one of the most effective factors on indoor VOC levels (Jia et al., 2008b).

In terms of potential sources of VOCs, pesticide usage is common in all of the sampling sites, except in U-3 where the lowest VOCs levels occurred. No clear trend between naphthalene/air freshener usage and VOCs levels was observed. Nevertheless, higher VOCs levels were found in the sampling points where the home cleaning frequency was at least twice a week. Cleaning agents include a variety of VOCs, in addition to BTEX compounds (Wolkoff et al., 1998; Nazaroff and Weschler, 2004; Mentese et al., 2012). Studies showed that cleaning can increase the overall indoor VOCs and can induce sick building syndrome (SBS) symptoms (Apter et al., 1994; Vejrup, 1996; Franke et al., 1997; Wolkoff et al., 1998; Takeda et al., 2009). Also, some studies showed associations between wall painting and having new furniture at home and VOCs (Berry et al., 1996; Brown et al., 1996; Yriex et al., 2010; Pegas et al., 2011).

Floor number of the homes may influence the indoor VOCs levels by infiltration or ventilation, particularly at the traffic junctions or industrial areas. Indoor VOCs and $\mathrm{CO}_{2}$ levels were lower in homes located in urban and rural towns where the homes were on higher floors compared to those in homes located in the industrial town where the homes were on the first floor. Distance to traffic had a variable association with indoor $\mathrm{CO}_{2}$ and VOCs levels in this study. VOCs levels were found to be the lowest in U-2, which was far from traffic sources, whereas the highest VOCs were observed in industrial sampling sites, where proximity to the traffic sources was less. Thus, indoor VOCs were not directly influenced by just one factor such as traffic. In this case, industrial activity might have contributed to indoor VOC levels. Assimakopoulos et al. (2008) found higher indoor TVOC levels when the windows were kept open, indicating the contribution of outdoor VOC levels, while indoor $\mathrm{CO}_{2}$ levels were almost constant. Since there is no clear difference in outdoor $\mathrm{CO}_{2}$ levels among the sampling points, it is not possible to relate outdoor $\mathrm{CO}_{2}$ levels with either proximity to traffic source, or proximity to industrial activities. Similar variable trend was observed for the factors of last floor covering and wall painting times versus indoor VOCs levels, which have the potential to contribute to indoor VOC levels.

\section{Conclusions}

Residential exposures to VOCs and $\mathrm{CO}_{2}$ were assessed for about a year in different homes located in different towns. Briefly:

- No clear seasonal variations in VOC levels were observed at the sampling sites, indicating constant sources in the indoor environments for those VOCs throughout the year.

- Indoor $\mathrm{CO}_{2}$ levels were found to be higher than those measured outdoors. The highest indoor $\mathrm{CO}_{2}$ levels were found in industrial sampling points, whereas the lowest $\mathrm{CO}_{2}$ levels were found in urban sampling points.

- A connection was found between aspects of the outdoor environment (i.e. availability of potential sources of the air pollutants) and residential exposure to air pollution.

- Some activities (e.g. heating fuel type, house cleaning frequency, etc.) and factors (e.g. characteristics of the outdoor environment) influence residential exposure to VOCs and $\mathrm{CO}_{2}$.

- Floor number of the homes influenced the indoor VOCs and $\mathrm{CO}_{2}$ levels by infiltration or ventilation particularly at traffic junctions or industrial areas.

- Time spent at home by the occupants was linked with bad odor at home.

\section{Acknowledgements}

This study was financially supported by The Scientific and Technological Council of Turkey (TUBITAK). Project no: 112 Y059. The authors also thank to Mrs. Catherine Yigit for proofreading.

\section{References}

ANSI/ASHRAE Standard 62.1. (2016a), Ventilation for Acceptable Indoor Air Quality, ASHRAE, Atlanta, GA.

ANSI/ASHRAE Standard 62.2. (2016b), Ventilation and Acceptable Indoor Air Quality in Low-Rise Residential Buildings, ASHRAE, Atlanta, GA.

Apte M.G., Fisk W.J. and Daisy J.M. (2000), Associations between indoor $\left(\mathrm{CO}_{2}\right)$ concentrations and sick building syndrome symptoms in US Office Buildings: an analysis of the 1994-1996 BASE Study Data (LBNL 44385), Indoor Air, 10, 246-257.

Apter A., Bracker A., Hodgson M., Sidman J. and Leung W-Y. (1994), Epidemiology of the sick building Syndrome, J. Allergy Clin. Immunol., 94, 277-288.

Arif A.A. and Shah S.M. (2007). Association between personal exposure to volatile organic compounds and asthma among US adult population, Int. Arch. Occup. Environ. Health, 80, 711-719.

Assimakopoulos V.D., Saraga D., Helmis C.G., Stathopoulou O.I. and Halios C.H. (2008), An Experimental Study of the Indoor Air Quality in Areas of Different Use, Global NEST Journal, 10(2), 192-200.

Baek S.O., Kim Y.S. and Perry R. (1997), Indoor Air Quality in Homes, Offices and Restaurants in Korean Urban AreasIndoor/Outdoor Relationships, Atmos. Environ., 31, 529-44. 
Berry R.W., Brown V.M., Coward S.K.D., Crump D.R., Gavin M., Grimes C.P., Higham D.F., Hull A.V., Hunter C.A., Jeffery I.G., Lea R.G., Llewellyn J.W. and Raw G.J. (1996), Indoor air quality in homes. The BRE Indoor Environment Study. BRE Reports BR299 and BR300, CRC press, London.

Billionnet C., Gay E., Kirchner S., Leynaert B. and Annesi-Maesano I. (2011), Quantitative assessments of indoor air pollution and respiratory health in a population-based sample of French dwellings, Environ Res., 111, 425-434.

Brown V.M., Crump D.R. and Mann H.S. (1996), The effect of measures to alleviate the symptoms of asthma on concentrations of VOCS and formaldehyde in UK Homes. Proceedings of Indoor Air '96, Vol. 4, Indoor Air '96, Nagoya, pp. 69-74.

European Collaborative Action (ECA) - IAQ. (1997). Total Volatile Organic Compounds TVOC in Indoor Air Quality Investigations. Report No. 19, European Commission, Brussels.

EN 13779. (2007), Ventilation for non-residential buildings performance requirements for ventilation and roomconditioning systems. The new European standard. 2007, Brussels.

Franke D.L., Cole E.C. and Berry M.A. (1997), Cleaning for improved indoor air quality: an initial assessment of effectiveness, Indoor Air, 7, 41-54.

Heudorf U., Neitzert V. and Spark J. (2009), Particulate matter and carbon dioxide in classrooms - The impact of cleaning and ventilation, Int J. Hyg. Environ. Health, 212(1), 45-55.

ISO 16000-6. (2004). Determination of volatile organic compounds in indoor and test chamber air by active sampling on Tenax TA sorbent, thermal desorption and gas chromatography using MS/FID, indoor, ambient and workplace air sampling and analysis of volatile organic compounds by sorbent tube/thermal desorption/capillary gas chromatography Part 1: pumped sampling, ISO Geneva.

ISO 16017-2. (2003). Indoor, ambient and workplace air-Sampling and analysis of volatile organic compounds by sorbent tube/thermal desorption/capillary gas chromatography - Part 2: Diffusive sampling, ISO Geneva.

Jia C., Batterman S and Godwin C. (2008a), VOCs in industrial, urban and suburban neighborhoods, Part 1: indoor and outdoor concentrations, variation, and risk drivers. Atmos. Environ. 42, 2083-2100.

Jia, C., Batterman S. and Godwin C. (2008b), VOCs in industrial, urban and suburban neighborhoods, Part 2: factors affecting indoor and outdoor concentrations. Atmos. Environ. 42, 21012116.

Lee S.C. and Chang M. (2000). Indoor and outdoor air quality investigation at schools in Hong Kong, Chemosphere, 41, 109113.

Mentese S, Rad AY, Arısoy M, Güllü G. (2012), Multiple comparisons of organic, microbial, and fine particulate pollutants in typical indoor environments: diurnal and seasonal variations. J Air Waste Manag Assoc, 62(12), 138093.

Mentese S. and Tasdibi D. (2016a), Airborne bacteria levels in indoor urban environments: the influence of season and prevalence of sick building syndrome (SBS). Indoor Built Environ, 25(3), 563-580.
Mentese S, Mirici NA, Otkun MT, et al. (2015). Association between respiratory health and indoor air pollution exposure in Canakkale, Turkey, Build Environ, 93(1), 72-83.

Mentese S. and Tasdibi, D. (2016b), Estimation of sources and factors affecting indoor VOC levels using basic numerical methods, AIMS Environ Sci, 3(4), 827-841.

Mentese S., Arısoy M. Rad A.Y. Güllü G. (2009), Bacteria and fungi levels in various indoor and outdoor environments in Ankara, Turkey, CLEAN - Soil, Air, Water, 37(6), 487-493.

Mitchell C.S., Zhang J.F.J., Sigsgaard T., Jantunen M., Lioy P.J., Samson R. and Karol M.H. (2007), Current state of the science: health effects and indoor environmental quality, Environ. Health Perspect, 115, 958-964.

Mohamed M., Kang D. and Aneja V. (2002), Volatile Organic Compounds in Some Urban Locations in United States, Chemosphere, 47, 863-82.

Nazaroff W.W. and Weschler C.J. (2004), Cleaning products and air fresheners: exposure to primary and secondary air pollutants, Atmos. Environ., 38(18), 2841-2865.

Olesen B. (2004). International standards for the indoor environment, Indoor Air, 14(s7), 18-26.

Pegas P.N., Alves C.A., Evtyugina M.G., Nunes T., Cerqueira M., Franchi M., Pio C.A., Almeida S.M. and Freitas M.C. (2011), Indoor air quality in elementary schools of Lisbon in spring, Environmental Geochemistry and Health, 33(5), 455-468.

Rehwagen M., Schlink U. and Herbarth O. (2003), Seasonal Cycle of VOCs in Apartments, Indoor Air, 13, 283-91.

Satish U., Mendell M., Shekhar K., Hotchi T., Sullivan, D., Streufert S. and Fisk W. (2012), Is $\mathrm{CO}_{2}$ and indoor air pollutant? Direct effects of low-to moderate $\mathrm{CO}_{2}$ concentrations on human decision-making performance, Environ. Health Perpect., 120(12), 1671-1677.

Shendell D.G., Winer A.M., Weker R. and Colome S.D. (2004a). Evidence of inadequate ventilation in portable classrooms: results of a pilot study in Los Angeles county, Indoor Air, 14, 154-158.

Shendell D.G., Prill R., Fisk W.J., Apte M.G., Blake D. and Faulkner D. (2004b), Associations between classroom $\mathrm{CO}_{2}$ concentrations and student attendance in Washington and Idaho, Indoor Air, 14, 333-341.

Takeda M., Saijo Y., Yuasa M., Kanazawa A., Araki A. and Kishi R. (2009), Relationship between sick building syndrome and indoor environmental factors in newly built Japanese dwellings, Int. Arch. Occup. Environ. Health, 82(5), 583-595.

US EPA. (1999), Compendium Method for the Determination of Organic Compounds in Ambient Air, TO-17, EPA/625/R96010b.

US EPA. (2012). "Benzene", https://www3.epa.gov/airtoxics/hlthef/benzene.html

Vejrup K.V. (1996), The importance of chemical components in cleaning agents for the indoor environment. Ph.D. Thesis, National Institute of Occupational Health and Danish Technical University.

Wieslander G., Norback D., Bjornsson E., Janson C. and Boman G. (1996), Asthma and the indoor environment: the significance of formaldehyde and volatile organic compounds from newly painted indoor surfaces, Int. Arch. Occup. Environ. Health, 69(2), 115-124.

Wolkoff P., Schneider T., Kildes $\emptyset$ J., Degerth R., Jaroszewski M. and Schunk H. (1998), Risk in cleaning: chemical and physical exposure, Sci. Total Env., 215(1-2), 135-156. 
Yrieix C., Dulaurent A., Laffargue C., Maupetit F., Pacary T. and Uhde E. (2010). Characterization of VOC and formaldehyde emissions from a wood based panel: Results from an interlaboratory comparison, Chemosphere, 79(4), 414-419.

Zhang J. and Smith K.R. (1996), Hydrocarbon emissions and health risks from cookstoves in developing countries, J. Exposure Anal. Env. Epidemiol., 6(2), 147-161. 